\title{
ДОСЛІДЖЕННЯ ФУНКЦІОНАЛЬНОЇ АКТИВНОСТІ МОНОНУКЛЕАРНИХ КЛІТИН КРОВІ ЗА ПРОДУКЦІЕЮ ЦИТОКІНІВ ПІД ВПЛИВОМ ФОТОАКТИВНИХ TИТАНОВМІСНИХ НАНОМАТЕРІАЛIВ IN VITRO
}

\author{
РЯБОВОЛ В.М., КУРЧЕНКО А.І., ЯВОРОВСЬКИЙ О.П., САВЧЕНКО В.С., ТАРАН Н.В. \\ Національний медичний університет імені О.О. Богомольця
}

Зростаючий попит використання наноматеріалів викликає занепокоєння щодо їхнього потенційного шкідливого впливу на працівників в умовах нановиробництва. Потенційна роль наноматеріалів у розвитку та загостренні професійних захворювань розкривається експериментальними дослідженнями в умовах in vivo та in vitro [2, 3].

Протягом останніх десятиліть було встановлено, що провідна роль імунної системи в підтримці гомеостазу організму, в протиінфекційному і протипухлинному захисті, у розвитку запальних, алергічних, автоімунних та імунодефіцитних захворювань. 3'ясовано, що функції імунної системи людини можуть істотно змінюватися у бік посилення або пригнічення під дією багатьох ендогенних і екзогенних факторів навколишнього середовища, які здатні впливати на різні ланки імунної системи і змінювати силу, характер і напрям імунних реакцій. Основний шлях надходження наночастинок в умовах виробництва $є$ інгаляційний і перкутанний, що створює ризик до розвитку у операторів нанотехнологічних установок бронхіальної астми, алергічних ринітів, кон'юнктивітів, контактних дерматитів [1]. Дослідження шкідливого впливу наночастинок на імунну систему набуває пріоритетного значення в області сучасної імунотоксикології.

Для клінічного прогнозу виникнення і перебігу професійних захворювань у працівників нановиробництва важливим стає визначення чутливої ланки імунітету при впливі сучасних наноматеріалів, для яких характерні певні фізико-хімічні особливості, що впливають на механізм їх біологічної дії. При виготовленні нанопорошків мають місце ручні операції і тому $€$ ризик вдихання внаслідок забруднення повітря робочої зони пиловими частками як ультрамікроскопічного, так і нанодіапазону, а також потрапляння їх на одяг, шкіру та слизові оболонки працівника [4]. 3 сучасних даних літератури відомо, що наночастинки здатні долати біологічний бар'єр, розповсюджуватися по всьому організму та викликати відповідні реакції з боку різних органів і систем, в тому числі імунної.
Питання впливу фотоактивних наноматеріалів (нанотіO2, наноTіO2-Ag) на імунні реакції до кінця не вивчено, що потребує подальших досліджень в умовах in vivo та in vitro.

\section{META}

Вивчити вплив фотоактивних наноматеріалів на функціональну активність мононуклеарних клітин периферичної крові (РМВС) здорових донорів в умовах in vitro за продукцією цитокінів: IL-1, IL-4, IL-6, TNF- $\alpha$.

\section{МАТЕРІАЛИ ТА МЕТОДИ}

Об'єктами дослідження слугували нанопорошок діоксиду титану (наноТіО2, кристалічна форма - анатаз, $\approx$ 21-28 нм, питома поверхня 57,3 м²/г), нанокомпозит діоксиду титану з наносріблом (нанотіО2-Ag, $\approx 17-22$ нм), наносрібло (наноAg) розроблені Інститутом проблем матеріалознавства імені І.М. Францевича. Фотоактивні наночастинки ТіO2 характеризуються фотокаталітичними властивостями, завдяки яким знаходять своє застосування у очищенні (знезараженні) повітря і води, сонячних батареях та сенсорах. Допований наноТіО2 нанорозмірним сріблом ( $\approx 4 \% \mathrm{Ag})$, змінює фотокаталітичні властивості в сторону покращення для екологічного призначення.

У дослідженні взяли участь 30 здорових донорів-добровольців, у яких після інформованої згоди була взята периферична кров для дослідження in vitro.

Мононуклеарні клітини периферичної крові виділяли із застосуванням градієнта щільності фіколл-верографину $(1,076-1,078)$ і поміщали в культуральне середовище RPMI-1640, що містить 10\% ембріональної телячої сироватки, 40 мкг/мл гентаміцину, 5х10М 2-меркаптоетанол і 3\% L-глютаміну. Клітинну суспензію в концентрації $1,5 \times 10^{6}$ кл/мл інкубували 24 годин в СО2інкубаторі при $37^{\circ} \mathrm{C}$ без стимулюючого агента, при стимуляції мітогеном ФГА, в концентрації 30 мкг/мл, а також при стимуляції наноматеріалами: наноTіO2, наноTіO2-Ag і наноAg по 10 мкл суспензій наночастинок в концентрації 3 мг/мл (30 мкг/мл). 
Досліджувану дозу наноматеріалів розраховували, опираючись на масову концентрацію наночасток у кубометрі повітря робочої зони 5 мкг/M ${ }^{3}$ [7], далі було вирахувано об'єм повітря, який проходить через легені працівника нановиробництва за 20 років стажу та розраховано, що накопичення (поглинання) наночасток з повітря становитиме 10\%. Для досліджуваних наноматеріалів використовувалися концентрації розрахованої дози 0,3 мг/кг наночастинок, що відповідає потенційному накопиченню наночастинок в організмі відповідної категорії працівників нановиробництва за 20 років стажу.

Імуноферментним методом (ELISA) в супернатантах мононуклеарних клітин визначали концентрацію цитокінів (IL-1, IL-6, IL-4, TNF- $\alpha$ ), тестування проводилося за допомогою імуноферментного аналізатора «Stat Fax-303 Plus».

Статистична обробка інформації проведена за допомогою пакету програм «MedStat V.5.2.». Математична обробка отриманих результатів проводилася з урахуванням перевірки показників на нормальний розподіл за критерієм-W Шапіро-Уілка. Для статистичної обробки використовувалися параметричні критерії статистики: критерій Стьюдента, дисперсійний аналіз, метод множинних порівнянь Шеффе; непараметричні: W-критерій Вілкоксона, ранговий однофакторний аналіз Крускала-Уолліса, множинні порівняння за критерієм Данна. Відмінність вважали статистично значимою при $\mathrm{P}<0,05$.

\section{РЕЗУЛЬТАТИ ТА ЇХ ОБГОВОРЕННЯ}

Оцінка функціональної активності мононуклеарних клітин за продукцією IL-1 під впливом наноматеріалів у донорів в умовах in vitro. IL-1 - один з важливих прозапальних цитокінів, який продукується активованими макрофагами, а також може продукуватися й іншими клітинами: епітеліальними, ендотеліальними, гліальними, фібробластами, кератиноцитами. Роль IL-1 в імунній відповіді надзвичайно важлива. Продукція IL-1 слугує регуляторним механізмом у відповідь організму на пошкодження. Під його впливом у момент презентації макрофагами антигенного пептиду Т-лімфоцитамхелперам 1 типу останні починають продукувати IL-2. Крім того, одночасно під впливом IL-1 на Т-лімфоцитах експресуються рецептори до IL-2. Таким шляхом, створюються умови для подальшої проліферації лімфоцитів і дозрівання клону специфічно активованих клітин. IL-1 підсилює експресію молекул клітинної адгезії, що призводить до підвищення продукції інших прозапальних цитокінів - IFN- $\alpha$, TNF- $\alpha$, IL-6, IL-8 і активує гранулоцити, фібробласти, остеокласти, кератиноцити, NK-клітини [4]. У зв'язку з цим, вкрай важливим є вивчення можливого впливу фотоактивних наноматеріалів на продукцію IL-1 мононуклеарними клітинами донорів при впливі на них в умовах in vitro. Отримані результати представлені на рисунку 1.

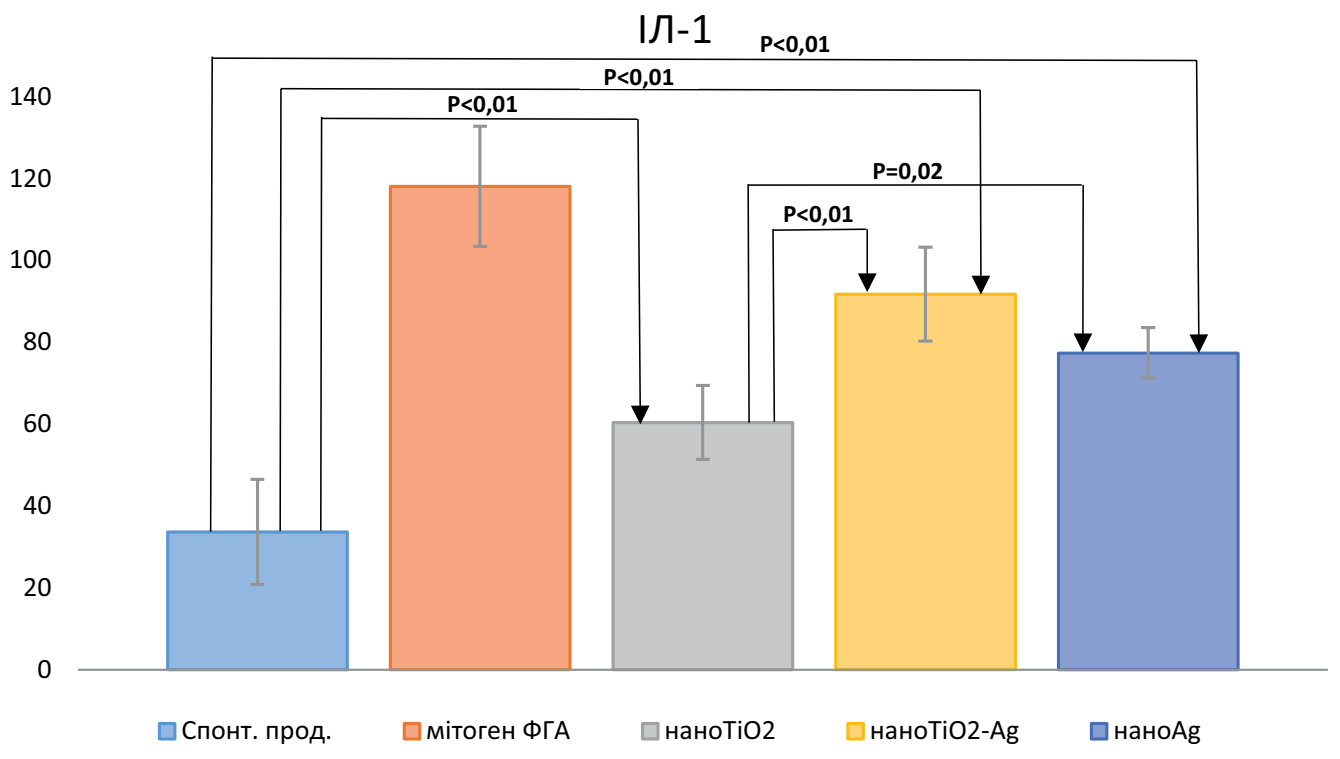

Рисунок 1. Порівняльна продукція IL-1 мононуклеарними клітинами in vitro у донорів під впливом фотоактивних наноматеріалів

Як з'ясувалося (Рис.1) в процесі дослідження, спонтанна продукція IL-1 мононуклеарними клітинами периферичної крові в системі in

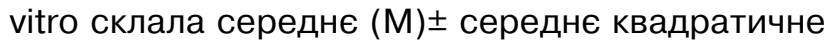

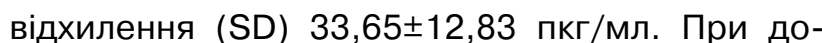
даванні мітогена фітогемоглютиніна (мітоген ФГА) продукція клітинами IL-1 підвищувалася до $118,1 \pm 14,73$ пкг/мл. При стимуляції монону- 
клеарних клітин наноматеріалами у відповідних концентраціях наноTiO2 продукція IL-1 підвищилась до $60,38 \pm 9,04$ пкг/мл (в 1,79 разів $\mathrm{P}<0,01)$,

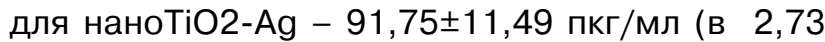

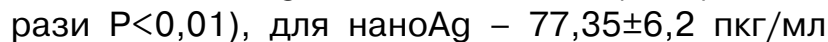
(2,3 рази $\mathrm{P}<0,01)$ у порівнянні зі спонтанною продукцією. Порівнюючи вплив наноматеріалів між собою на функціональну активність мононуклеарних клітин під дією наноTіO2-Ag, спостерігаємо збільшення продукції IL-1 в 1,52 рази $(P<0,01)$ та під дією наноAg в 1,28 рази $(P=0,02)$ в порівнянні з нанотіО2.
Оцінка функціональної активності мононуклеарних клітин за продукцією IL-6 під впливом нанокомпозитних матеріалів у донорів в умовах in vitro. IL-6, як відомо, регулює імунну відповідь, фазу гострої відповіді, запалення, онкогенез і гемопоез. Однією з основних функцій IL-6 є peгуляція процесів дозрівання антитіло продукуючих клітин із В-лімфоцитів і самої продукції імуноглобулінів. Результати дослідження продукції in vitro IL-6 під впливом нанокомпозитних матеріалів представлені на рисунку 2.

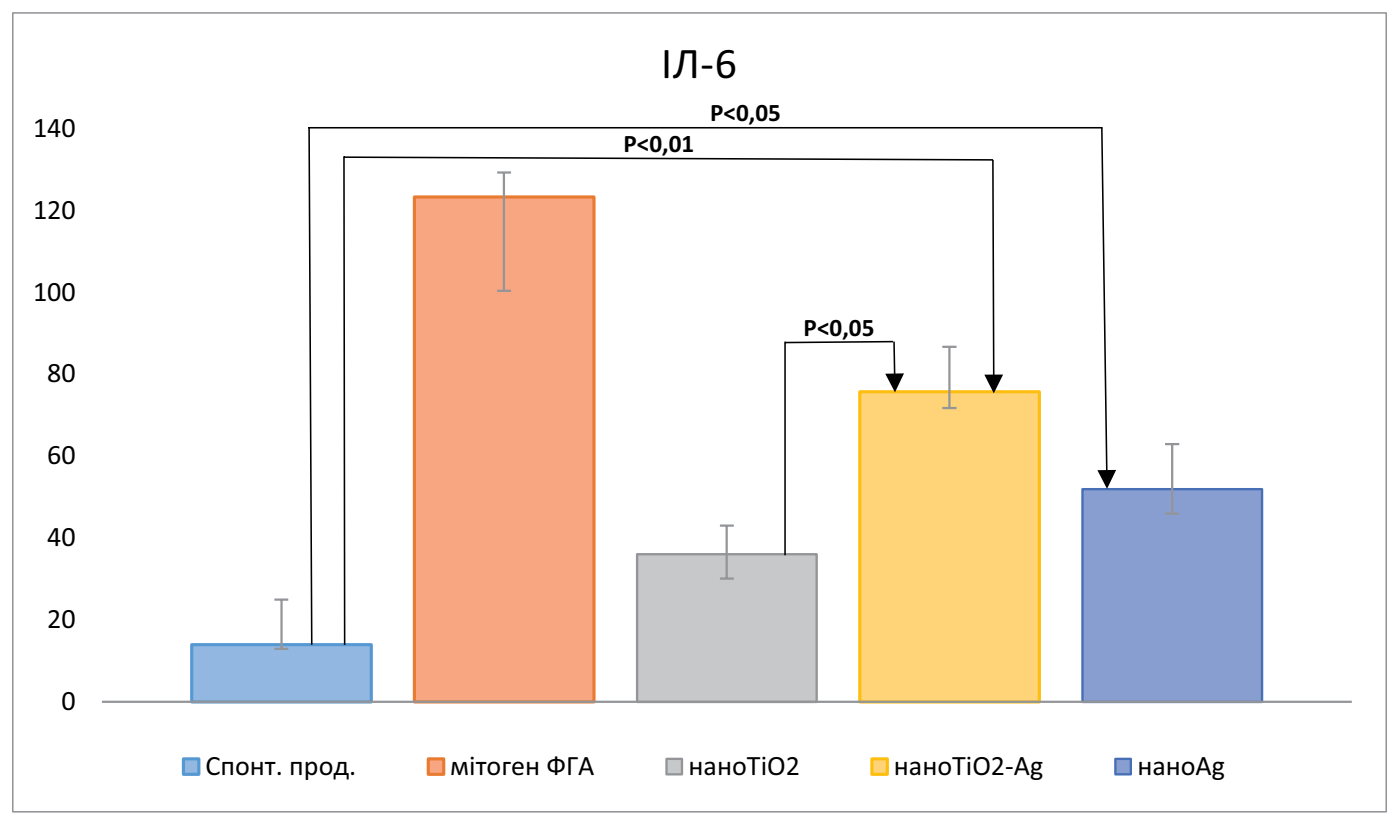

Рисунок 2. Порівняльна продукція IL-6 мононуклеарними клітинами in vitro у донорів під впливом фотоактивних наноматеріалів

Як видно з рис. 2, спонтанна продукція IL-6 мононуклеарними клітинами крові характеризувалася рівнем медіани (М) (95\% вірогідний інтервал, ВІ) 14,0 (BI 12,6-25,8) пкг/мл. Під впливом мітогену ФГА спостерігалося підвищення продукції IL-6 до рівня 123,4 (BI 100,0$129,7)$ пкг/мл. При додаванні до мононуклеарних клітин наноматеріалів у відповідних концентраціях наноTіO2-Ag, продукція IL-6 збільшилась до 75,8 (BI 71,8-87,4) пкг/мл (в 5,41 раз $\mathrm{P}<0,01$ ), наноAg - 52,0 (BI 46,0-63,1) пкг/мл (в $3,71$ разів $P<0,05)$ в порівнянні зі спонтанною продукцією. Порівнюючи вплив наноматеріалів між собою на функціональну активність мононуклеарних клітин за продукцією IL-6, спостерігаємо при додаванні наноTіO2-Ag збільшення в 2,1 рази $(\mathrm{P}<0,05)$ в порівнянні при дії наHOTiO2.

Оцінка функціональної активності мононуклеарних клітин крові за продукцією TNF- $\alpha$ під впливом наноматеріалів у донорів в умовах in vitro. Фактор некрозу пухлин (TNF- $\alpha$ ) продукується різними типами клітин, включаючи моноцити-макрофаги, Т- і В-лімфоцити. TNF- $\alpha$ відноситься до класичних прозапальних цитокінів, який здатний активувати респіраторний вибух у нейтрофільних лейкоцитах та призводить до посилення кілінгової активності фагоцитуючих клітин. Крім того, TNF- $\alpha$ посилює синтез лімфокінів хелперними Т-лімфоцитами і стимулює ріст В-клітин. У високій концентрації він $€$ важливим медіатором, що викликає розвиток ендотоксин-індукованого септичного шоку. TNF- $\alpha$ сприяє проліферації Т- і В-лімфоцитів, активації ЕК-клітин і макрофагів, підсилює продукцію простагландинів, за посередництва яких реалізуються багато токсичних ефектів [4]. Отримані результати впливу різних нанокомпозитних матеріалів на продукцію TNF- $\alpha$ в умовах in vitro представлені на рис.3. 


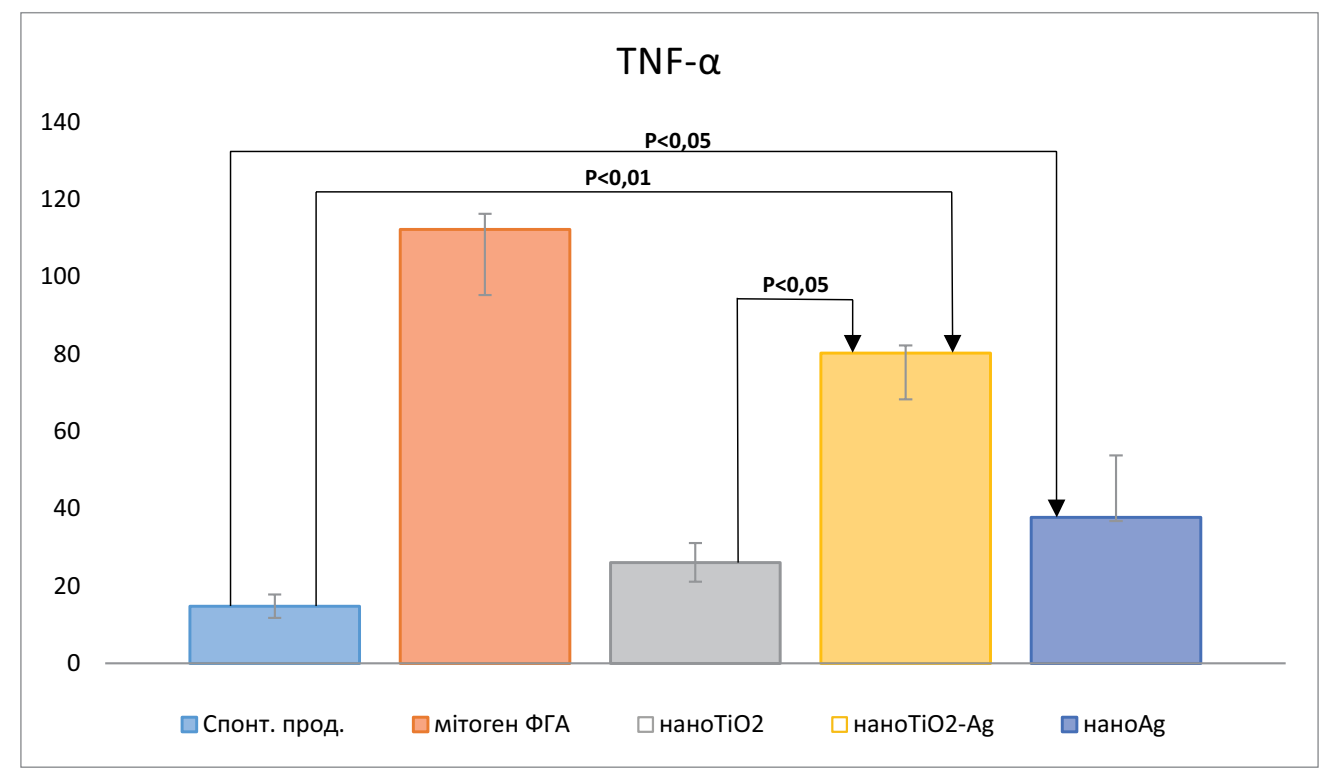

Рисунок 3. Порівняльна продукція TNF- мононуклеарними клітинами in vitro у донорів під впливом фотоактивних наноматеріалів

Як видно з рис. 3, медіана спонтанної продукції TNF- $\alpha$ становила 14,8 (ВI 11,7-18) пкг/ мл. Під впливом мітогену ФГА виявлено підвищення продукції TNF- $\alpha$ до 112,3 (BI 94,9-116,3) пкг/мл. При стимуляції мононуклеарних клітин наноматеріалами у відповідних концентраціях, наноTiO2-Ag продукція TNF- $\alpha$ збільшилась до 80,3 (BI 68,0-82,4) пкг/мл (в 5,43 рази $\mathrm{P}<0,01$ ), наноAg - 37,8 (BI 36,7-54,2) пкг/мл (в 2,55 рази $\mathrm{P}<0,05)$ в порівнянні зі спонтанною продукцією. Порівнюючи вплив наноматеріалів між собою на функціональну активність мононуклеарних клітин за продукцією TNF- $\alpha$, спостерігаємо при додаванні наноTіO2-Ag збільшення в 3,08 рази $(P<0,05)$ в порівнянні при дії наноТіО2.

Як випливає з наведеного, експерименти в умовах in vitro показали, що фотоактивні наноматеріали здатні підвищувати функціональну активність мононуклеарних клітин по продукції IL-1, IL-6 та TNF- , які в нормі регулюють взаємодію клітин імунної системи, а при запаленні виконують функції активаторів запалення і тканинного пошкодження.

Визначення функціональної активності мононуклеарних клітин крові за продукції IL-4 під впливом наноматеріалів у донорів в умовах in vitro. Як відомо, IL-4 індукує диференціювання попередників В-лімфоцитів, викликає проліферацію вже активованих В-клітин та експресію клітинних рецепторів до IgE. Дія IL-4 на ріст і диференціювання В-лімфоцитів опосередковано направлена на зв'язування IL-4 зі специфічними рецепторами на їх поверхні.

Вважають, що IL-4, який індукує проліферацію В-лімфоцитів, посилює експресію рецепто- рів до Fc-фрагменту IgE i $є$ антагоністом IFN- $\alpha$, пригнічуючи продукцію IL-1, TNF- $\alpha$, IL-6, IL-8 i цитотоксичну активність Т-лімфоцитів, відіграє важливу роль у формуванні алергічних реакцій негайного типу.

Сьогодні існує теорія, що алергічні захворювання викликаються порушенням регуляції імунної системи внаслідок активації CD4+ Т хелперів 2 типу і підвищеною секрецією цитокінів, включаючи IL-4, який сприяє синтезу IgE, активізації тучних клітин та еозинофілів. В результаті розвивається алергічне запалення до розвитку алергічних захворювань (бронхіальні астма, алергічний риніт та дерматит) [8].

Отримані нами результати визначення функціональної активності мононуклеарів периферичної крові по продукції IL-4 під впливом нанокомпозитних матеріалів у донорів в умовах in vitro представлені на рисунку 4.

Як видно з рис. 4, спонтанна продукція IL-4 клітинами мононуклеарного ряду характеризувалася рівнем 17,6 (BI 16,1-18,7) пкг/мл. Під впливом мітогену ФГА спостерігалося підвищення продукції IL-4 до рівня 84 (BI 78-98,8) пкг/мл. При стимуляції мононуклеарних клітин наноматеріалами у відповідних концентраціях наноTіO2-Ag, продукція IL-4 збільшилась до 60,8 (BI 52,8-77,6) пкг/мл (в 3,45 рази $\mathrm{P}<0,01$ ), наноAg - 41,7 (BI 34,7-49,1) пкг/мл (в 2,37 рази $\mathrm{P}<0,01)$ в порівнянні зі спонтанною продукцією. Порівнюючи вплив наноматеріалів між собою на функціональну активність мононуклеарних клітин за продукцією IL-4, спостерігаємо, що при додаванні наноTіO2-Ag збільшується в 2,07 разу $(\mathrm{P}<0,01)$ у порівнянні з наноТіO2. 


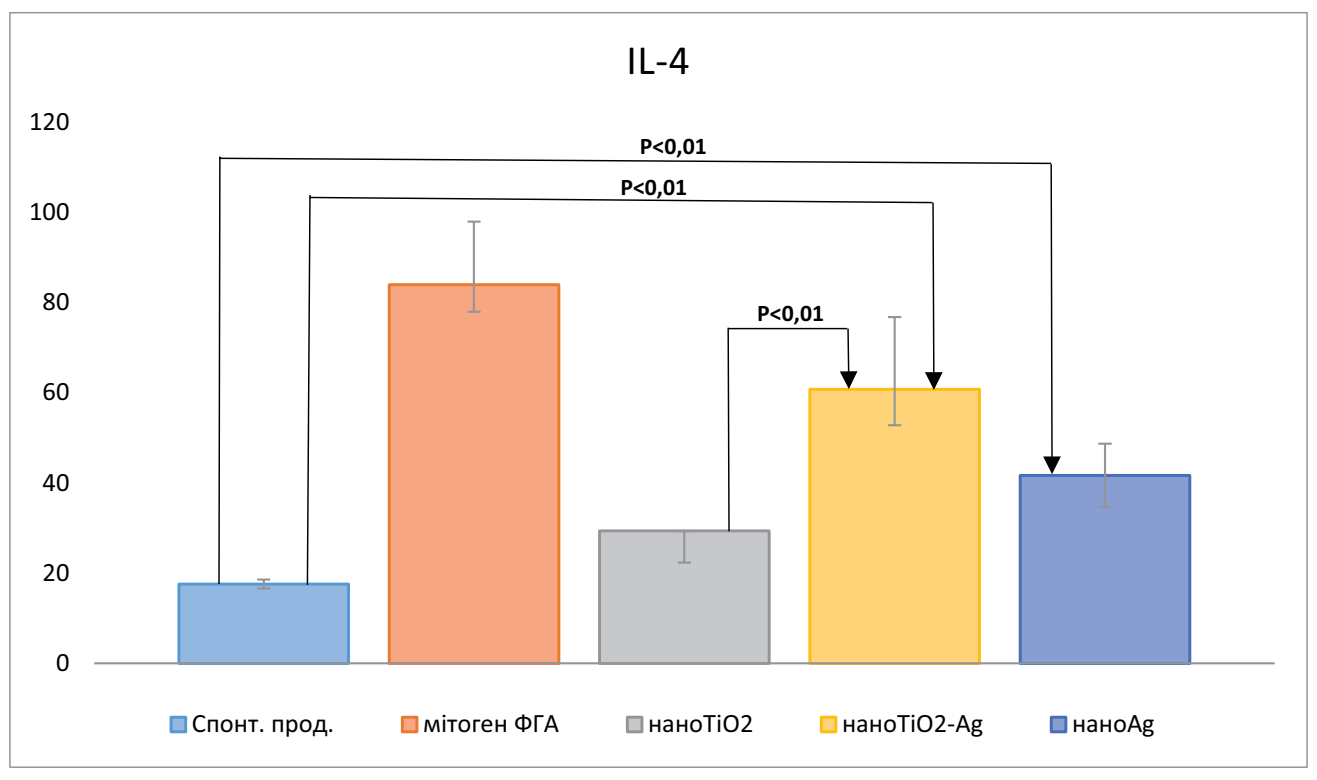

Рисунок 4. Порівняльна продукція IL-4 мононуклеарними клітинами in vitro у донорів під впливом фотоактивних наноматеріалів

Із зазначеного випливає, що вивчення in vitro впливу сучасних фотоактивних наноматеріалів на імунокомпетентні клітини є одним з ключових параметрів при визначенні їх імуноспецифічної активності і може слугувати основою для оптимізації подальших профілактичних заходів для відповідної категорії працівників нановиробництва.

Насамперед, це стосується вивчення функціональної активності імунокомпетентних клітин шляхом аналізу їх проліферативної здатності і особливо продукції цитокінів, які відіграють роль медіаторів, що забезпечують кооперативну міжклітинну взаємодію. Патогенетичним обґрунтуванням виникнення імунодефіцитного стану у людини, що контактує з нанокомпозитними матеріалами, може слугувати зниження якості міжклітинної взаємодії між мононуклеарними клітинами периферичної крові, що пов'язано з порушеннями регуляції синтезу цитокінів [2, 4]. В останні роки, завдяки розвитку методів кількісного визначення рівнів продукції цитокінів був досягнутий значний прогрес у розумінні ролі цих речовин в нормі і при патології. Вивчення продукції цитокінів дозволяє отримати інформацію про функціональну активність різних типів імунокомпетентних клітин; про тяжкість запального процесу, його перехід на системний рівень, прогноз та стадії розвитку ряду важких ускладнень.

\section{ВИСНОВКИ}

1. Експерименти в умовах in vitro показали, що наноматеріали у концентраціях 30 мкг/мл для наноTiO2-Ag та наноAg здатні підвищувати функціональну активність мононуклеарних клітин периферичної крові за продукцією прозапальних цитокінів IL-1, IL-6, TNF- $\alpha$ та продукцію IL-4 у донорів $(P<0,05)$, що свідчить про потенційний вплив на формування хронічного запалення та алергічних реакцій у відповідній категорії працівників нановиробництва.

2. Під впливом наноматеріалу у концентрації 30 мкг/мл наноТіО2 на мононуклеарні клітини периферичної крові спостерігаємо статистично значиме збільшення продукції IL-1 (P<0,01), а продукція IL-6, TNF- $\alpha$, IL-4 не $є$ статистично значимою в порівнянні із спонтанною продукцією.

3. Функціональна активність мононуклеарних клітин периферичної крові за продукцією цитокінів (IL-1, IL-6, TNF- $\alpha$, IL-4) зростає під впливом досліджуваних наночастинок у відповідних концентраціях у ряді нанотіO2, наноAg, наноTіO2-Ag ( $\mathrm{P}<0,05)$, що свідчить про найбільшу потенційну небезпеку імунотоксичності наноTіO2-Ag для працівників, що працюють у відповідних умовах нановиробництва.

4. Одержані результати будуть враховані при обґрунтуванні гігієнічних нормативів для наноTiO2, наноAg, наноTіO2-Ag в повітрі робочої зони.

\section{ЛITEPATУPA}

1. Slavin RG. Update on occupational rhinitis and asthma. Allergy Asthma Proc 31:437-43.doi: 10.2500/aap.2010.31.3379 .

2. Di Giampaolo L, Cavallucci E, Braga $M$, Renzetti A, Schiavone C, Quecchia C, et al. The persistence of allergen exposure favors pulmonary function decline in workers with allergic occupational asthma. Int Arch Occup Environ Health. 2012;85:181-8. doi: 10.1007/ s00420-011-0653-4.

3. ISO/TR 27628. Workplace atmospheres. Ultrafine, nanoparticle and nano-structured 
aerosols. Inhalation exposure characterization and assessment, 2007. n.d.

4. Солоха Н.В., Яворовський О.П., Карлова О.О., Курченко А.І., Савченко В.С., Функціональна активність мононуклеарних клітин крові за продукцією цитокінів під дією нанокомпозитних матеріалів в умовах in vitro, Імунологія та алергологія: наука i практика. 2'2015, с.94-98.

5. Bekker C, Brouwer DH, Tielemans E, Pronk A. Industrial production and professional application of manufactured nanomaterials-enabled end products in Dutch industries: potential for exposure. Ann Occup Hyg. 2013;57:314-27. doi:10.1093/annhyg/mes072.

6. Zhu M, Li Y, Shi J, Feng W, Nie G, Zhao $Y$. Exosomes as extrapulmonary signaling conveyors for nanoparticle-induced systemic immune activation. Small. 2012;8:404-12. doi:10.1002/smll.201101708.

7. ЯворовськийО.П., Солоха Н.В., ВеремейМ.І., Карлова О.О., Бобир В.В., Чоботар А.П. Гігієнічна оцінка виробничих чинників як основа управління ризиками у роботі операторів з одержання нанопорошків нітриду титану, дисиліциду хрому і діоксиду цирконію, Довкілля та здоров'я. 2016 №4 (80), с.63-68.

8. Attia, M., \& Saber, H. (2014). Role played by T-helper 2 in resetting the cytokine balance in allergic patients. The Egyptian Journal Of Internal Medicine, 26(3), 124-129. doi: 10.4103/1110-7782.145311.

\section{РЕЗЮME \\ ДОСЛІДЖЕННЯ ФУНКЦІОНАЛЬНОӦ АКТИВНОСТІ МОНОНУКЛЕАРНИХ КЛІТИН КРОВІ ЗА ПРОДУКЦІЕЮ ЦИТОКІНІВ ПІД ВПЛИВОМ ФОТОАКТИВНИХ ТИТАНОВМІСНИХ HAHOMATEPIAЛIB IN VITRO}

Рябовол В.М., Курченко А.І., Яворовський О.П. Савченко В.С., Таран Н.В.

Національний медичний університет імені О.О. Богомольця

Мета роботи. Вивчити вплив фотоактивних наноматеріалів на функціональну активність мононуклеарних клітин периферичної крові (РМВС) здорових донорів в умовах in vitro за продукцією цитокінів: IL-1, IL-4, IL-6, TNF- $\alpha$.

Матеріали і методи. Об'єктами дослідження слугували: нанопорошок діоксиду титану кристалічної форми - анатаз з розміром наночастинок 21-28 нм, нанокомпозит діоксиду титану з наносріблом $4 \% 3$ розміром наночастинок 17-22 нм та нанорозмірне срібло розроблені Інститутом проблем матеріалознавства імені І.М. Францевича.

Мононуклеарні клітини периферичної крові культивували, попередньо ї виділивши з периферичної крові донорів-добровольців, далі клітинну суспензію інкубували без стимулюючого агента та при стимуляції мітогеном ФГА в концентрації 30 мкг/мл, а також з додаванням досліджуваних наноматеріалів в концентраціях 30 мкг/мл, потім визначали концентрацію цитокінів імуноферментним методом.

Результати. При стимуляції мононуклеарних клітин наноматеріалами у відповідних концентраціях наноTіO2 продукція IL-1 підвищилась до 60,38 $\pm 9,04$ пкг/мл ( в 1,79 разів $\mathrm{P}<0,01)$, для наноТіO2-Ag $91,75 \pm 11,49$ пкг/мл (в 2,73 рази $\mathrm{P}<0,01)$, для наноAg

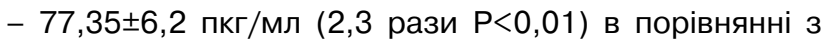
спонтанною продукцією. При додаванні до мононуклеарних клітин наноматеріалів у відповідних концентраціях наноTiO2-Ag продукція IL-6 збільшилась до 75,8 (BI 71,8-87,4) пкг/мл (в 5,41 раз $\mathrm{P}<0,01)$, наноAg - 52,0 (BI 46,0-63,1) пкг/мл (в 3,71 раз $\mathrm{P}<0,05)$ в порівнянні з спонтанною продукцією. При стимуляції мононуклеарних клітин наноматеріалами у відповідних концентраціях наноTіO2-Ag, продукція TNF- $\alpha$ збільшилась до 80,3 (BI 68,0-82,4) пкг/мл (в 5,43 рази $\mathrm{P}<0,01)$, наноAg - 37,8 (ВІ 36,7-54,2) пкг/мл (в 2,55 рази $\mathrm{P}<0,05)$ в порівнянні зі спонтанною продукцією. При стимуляції мононуклеарних клітин наноматеріалами у відповідних концентраціях, наноTіO2-Ag продукція IL-4 збільшилась до 60,8 (ВІ 52,8-77,6) пкг/мл (в 3,45 рази $\mathrm{P}<0,01)$, наноAg - 41, 7 (ВІ 34,7-49,1) пкг/мл (в 2,37 рази $\mathrm{P}<0,01)$ в порівнянні зі спонтанною продукцією.

Висновки. Експерименти в умовах in vitro показали, що наноматеріали у концентраціях 30 мкг/мл для наноTiO2-Ag та наноAg здатні підвищувати функціональну активність мононуклеарних клітин периферичної крові за продукцією прозапальних цитокінів IL-1, IL6 , TNF- $\alpha$ та продукцію IL-4 у донорів $(P<0,05)$, що свідчить про потенційний вплив на формування хронічного запалення та алергічних реакцій у відповідній категорії працівників нановиробництва.

Ключові слова: наночастинки, імунотоксикологія, нанодіоксид титану, композит нанодіоксиду титану 3 наносріблом, цитокіни IL-1, IL-6, TNF- $\alpha$, IL-4.

\section{PЕЗЮME \\ ИССЛЕДОВАНИЕ ФУНКЦИОНАЛЬНОЙ АКТИВНОСТИ МОНОНУКЛЕАРНЫХ КЛЕТОК КРОВИ С ПРОДУКЦИЕЙ ЦИТОКИНОВ ПОД ВЛИЯНИЕМ ФОТОАКТИВНЫХ ТИТАНОСОДЕРЖАЩИХ НАНОМАТЕРИАЛОВ IN VITRO \\ Рябовол В.М., КУрченко А.И., Яворовский А.П., Савченко В.С., Таран Н.В. \\ Национальный медицинский университет имени А.А. Богомольца}

Цель работы. Изучить влияние фотоактивных наноматериалов на функциональную активность мононуклеарных клеток периферической крови (РМВС) здоровых доноров в условиях in vitro за продукцией цитокинов: IL-1, IL-4, IL-6, TNF- $\alpha$.

Материалы и методы. Объектами исследования служили нанопорошок диоксида титана кристаллической формы - анатаз с размером наночастиц 21-28 нм, нанокомпозит диоксида титана с наносеребром 4\% с размером наночастиц 17-22 нм и наноразмерное серебро разработаны Институтом проблем материаловедения имени И.М. Францевича. 
Мононуклеарные клетки периферической крови культивировали, предварительно их выделив из периферической крови доноров-добровольцев, дальше клеточную суспензию инкубировали без стимулирующего агента и при стимуляции митогеном ФГА в концентрации 30 мкг/мл, а также с добавлением исследуемых наноматериалов в концентрациях 30 мкг/ мл, затем определяли концентрацию цитокинов иммуноферментным методом.

Результаты. При стимуляции мононуклеарных клеток наноматериалами в соответствующих концентрациях, наноТіO2 продукция IL-1 повысилась до $60,38 \pm 9,04$ пкг/мл (в 1,79 раз $\mathrm{P}<0,01$ ), для наноTіO2$\mathrm{Ag}-91,75 \pm 11,49$ пкг/мл (в 2,73 раза $\mathrm{P}<0,01)$, для наноAg $-77,35 \pm 6,2$ пкг/мл $(2,3$ раза $P<0,01)$ по сравнению со спонтанной продукцией. При добавлении к мононуклеарным клеткам наноматериалов в соответствующих концентрациях, наноTіO2-Ag продукция IL-6 увеличилась до 75,8 (Cl 71,8-87,4) пкг/мл (в 5,41 раз $\mathrm{P}<0,01)$, наноAg - 52,0 (Cl 46,0-63,1) пкг/ мл (в 3,71 раз $\mathrm{P}<0,05)$ по сравнению со спонтанной продукцией. При стимуляции мононуклеарных клеток наноматериалами в соответствующих концентрациях, наноTiO2-Ag продукция TNF- $\alpha$ увеличилась до $80,3$ (Cl 68,0-82,4) пкг/мл (в 5,43 раза $\mathrm{P}<0,01)$, наноAg - 37,8 (Cl 36,7-54,2) пкг/мл (в 2,55 раза $\mathrm{P}<0,05)$ по сравнению со спонтанной продукцией. При стимуляции мононуклеарных клеток наноматериалами в соответствующих концентрациях, наноTіO2-Ag продукция IL-4 увеличилась до 60,8 (Cl 52,8-77,6) пкг/мл (в 3,45 раза $\mathrm{P}<0,01)$, наноAg - 41,7 (Cl 34,7-49,1) пкг/ мл (в 2,37 раза $\mathrm{P}<0,01)$ по сравнению со спонтанной продукцией.

Выводы. Эксперименты в условиях in vitro показали, что наноматериалы в концентрациях 30 мкг/ мл для наноTіO2-Ag и наноAg способны повышать функциональную активность мононуклеарных клеток периферической крови с продукцией провоспалительных цитокинов IL-1, IL-6, TNF- $\alpha$ и продукцию IL-4 у доноров ( $\mathrm{P}<0,05)$, что свидетельствует о потенциальном воздействии на формирование хронического воспаления и аллергических реакций в соответствующей категории работников нанопроизводства.

Ключевые слова: наночастицы, иммунотоксикология, нанодиоксид титана, композит нанодиоксида титана с наносеребром, цитокины IL-1, IL-6, TNF- $\alpha$, IL-4

\section{SUMMARY}

\section{A STUDY OF THE INFLUENCE OF PHOTOACTIVE TITANIUM COMPOSITE NANOPARTICLES ON THE FUNCTIONAL ACTIVITY OF CYTOKINE-PRODUCING MONONUCLEAR BLOOD CELLS IN VITRO}

Riabovol V., Kurchenko A., Yavorovskyi A., Savchenko V., Taran N.

Bogomolets National Medical University

Objective. To study the effect of photoactive nanoparticles on the functional activity of peripheral mononuclear blood cells (PMBC) of healthy donors for the in-vitro production of cytokines: IL-1, IL-4, IL-6, TNF- $\alpha$.
Materials and methods. Subjects used in the study are: crystalline titanium dioxide nanopowder - anatase with a nanoparticle size of 21-28 nm; nanocomposite of titanium dioxide with $4 \%$ nanosilver, nanoparticle size 17$22 \mathrm{~nm}$; nanosized silver; developed by the Frantsevich Institute of Materials Science.

Mononuclear cells of peripheral blood were cultured ahead of time by deriving them from peripheral blood of volunteer donors. The cell suspension was further incubated without a stimulating agent and with PHA stimulation using mitogen (30 $\mathrm{\mu g} / \mathrm{ml}$ concentration), as well as with the addition of the studied nanoparticles $(30 \mu \mathrm{g} /$ $\mathrm{ml}$ concentration). Finally, the concentration of cytokines was determined by means of an immunosorbent assay.

Results. Compared to spontaneous production, the stimulation of mononuclear cells with nanoparticles in the according concentration of nanoTiO2 resulted in the production of the IL-1 increasing to $60.38 \pm 9.04 \mathrm{pkg} /$ $\mathrm{ml}(1.79$ times $\mathrm{P}<0.01)$, for nanoTiO2-Ag $-91.75 \pm 11.49$ $\mathrm{pkg} / \mathrm{ml}(2.73$ times $\mathrm{P}<0.01)$, for nanoAg $-77.35 \pm 6.2$ $\mathrm{pkg} / \mathrm{ml}(2.3$ times $\mathrm{P}<0.01)$.

When nanoparticles were added to the mononuclear cells in the according concentration of nanoTiO2-Ag, the production of IL-6 increased to $75.8(\mathrm{Cl} 71.8-87.4) \mathrm{pkg} /$ $\mathrm{ml}$ (5.41 times $\mathrm{P}<0.01)$, nanoAg - 52,0 (Cl 46.0-63.1) $\mathrm{pkg} / \mathrm{ml}$ (3.71 times $\mathrm{P}<0.05)$, compared to spontaneous production.

When mononuclear cells were stimulated with nanoparticles in the according concentration of nanoTiO2-Ag, the production of TNF- $\alpha$ increased to $80.3(\mathrm{Cl}$ 68.0-82.4) $\mathrm{pkg} / \mathrm{ml}$ (5.43 times $\mathrm{P}<0.01)$, nanoAg $-37,8$ (Cl 36.7-54.2) $\mathrm{pkg} / \mathrm{ml}(2.55$ times $\mathrm{P}<0.05)$, compared to spontaneous production.

Compared to spontaneous production, the stimulation of mononuclear cells with nanoparticles in the according concentration of nanoTiO2-Ag resulted in the production of IL-4 increasing to $60.8(\mathrm{Cl} 52.8-77.6) \mathrm{pkg} /$ $\mathrm{ml}$ (3.45 times $\mathrm{P}<0.01)$, nanoAg - 41,7 (Cl 34.7-49.1) $\mathrm{pkg} / \mathrm{ml}(2.37$ times $\mathrm{P}<0.01)$.

Conclusion. The in vitro experiments have evidenced that nanoparticles at a concentration of $30 \mu \mathrm{g} /$ $\mathrm{ml}$ for nanoTiO2-Ag and nanoAg are central in increasing functional activity of $\mathrm{PMBC}$ producing proinflammatory cytokines IL-1, IL-6, TNF- $\alpha$ and producing IL-4 in donors $(P<0.05)$. The aforementioned data demonstrates a negative effect of nanoparticles on nanotechnology industry workers causing them to develop chronic inflammatory response and allergic reactions.

Key words: nanoparticles, immunotoxicology, titanium dioxide nanoparticles, nanoparticles of composite titanium dioxide with silver, cytokines IL-1, IL-6, TNF- $\alpha$, IL-4.ціï 30.08.2021p. 
АВТОРСЬКА ДОВІДКА

\author{
- Рябовол Василь Миколайович \\ аспірант кафедри гігієни та екології №2 \\ Національного медичного університету \\ імені 0.0. Богомольця \\ Адреса: 03057, просп. Перемоги, 34 \\ Київ, Україна \\ Тел.: 0969149464 \\ E-mail: riabovol1@ukr.net
}

\section{- Курченко Андрій Ігорович} доктор медичних наук, професор, завідувач кафедри клінічної імунології та алергології із секцією медичної генетики Національного медичного університету імені 0.0. Богомольця. Адреса: Київ-79,

вул. Волоська, 47

Тел.: 050-581-23-45

E-mail: andriy.kurchenko@gmail.com

\section{- Яворовський Олександр Петрович}

доктор медичних наук, професор, академік НАМН України, завідувач кафедри гігієни та екології №2 Національного медичного університету імені 0.0. Богомольця Адреса: 01601, просп. Перемоги, 34, Київ, Україна

Тел.: 0444561487

E-mail: kgpnmu@ukr.net

\section{- Савченко Вікторія Станіславівна}

к.б.н., с.н.с. лаб. імунології дУ «ннститут нефрології НАМН України»

Адреса: Київ, вул. Дегтярівська, 17-В

Тел.: (044) 4865403

E-mail: utiainew@gmail.com

\section{- Таран Ніна Валеріївна}

кандидат медичних наук, доцент кафедри гігієни та екології №2 Національного медичного університету імені 0.0. Богомольця

Адреса: 01601, просп. Перемоги, 34, Київ, Україна

Тел.: 0444544930

E-mail: kgpnmu@ukr.net

\section{- Рябовол Василий Николаевич \\ аспирант кафедры гигиены и экологии №2 Национального медицинского университета имени А.А. Богомольца Адрес: 03057, просп. Победы, 34, Киев, Украина \\ Тел.: 0969149464 \\ E-mail: riabovol1@ukr.net}

\section{- Курченко Андрей Игоревич} доктор медицинских наук, профессор, заведующий кафедрой клинической иммунологии и аллергологии с секцией медицинской генетики Национального медицинского университета имени А.А. Богомольца.

Адрес: Киев-79, ул. Волошская, 47 Тел.: 050-581-23-45

E-mail: andriy.kurchenko@gmail.com

\section{- Яворовский Александр Петрович}

доктор медицинских наук, профессор, академик НАМН Украины, заведующий кафедрой гигиены и экологии №2 Национального медицинского университета имени А.А. Богомольца Адрес: 01601, ул. Победы, 34, Киев, Украина Тел.: 0444561487

E-mail: kgpnmu@ukr.net

\section{- Савченко Виктория Станиславовна}

к.б.н., С.н.с. лаб. иммунологии Гу «Институт нефрологии АМН Украины» Адрес: Киев, ул. Дегтяревская, 17-В Тел.: (044) 4865403

E-mail: utiainew@gmail.com

\section{- Таран Нина Валерьевна}

кандидат медицинских наук, доцент кафедры гигиены и экологии №2 Национального медицинского университета имени А.А. Богомольца Адрес: 01601, ул. Победы, 34, Киев, Украина

Тел.: 0444544930

E-mail: kgpnmu@ukr.net

\section{- Riabovol Vasyl}

PhD student of the Department of Hygiene and Ecology №2 of the National Medical University named after $\mathrm{O}$. Bogomolets Address: 01601, ave. Peremohy, 34, Kyiv, Ukraine

Tel.: 0969149464

E-mail: riabovol1@ukr.net

\section{- Kurchenko Andrii}

Doctor of Medical Sciences, Professor, Head of the Department of Clinical Immunology and Allergology with the Section of Medical Genetics of the National Medical University named after 0 . Bogomolets Address: Kyiv-80, str. Voloska, 47 Tel.: 050-581-23-45

E-mail: andriy.kurchenko@gmail.com

\section{- Yavorovskyi Alexander}

Doctor of Medical Sciences, Professor, Academician of the National Academy of Medical Sciences of Ukraine, Head of the Department of Hygiene and Ecology №2 of the National Medical University named after 0 . Bogomolets Address: 01601, ave. Peremohy, 34, Kyiv, Ukraine

Tel.: 0444561487

E-mail: kgpnmu@ukr.net

\section{- Savchenko Viktoriia}

Ph.D., senior researcher lab. of Immunology, Institute of Nephrology, National Academy of Medical Sciences of Ukraine

Address: Kyiv, str. Degtyarivska, 17-V

Tel.: (044) 4865403

E-mail: utiainew@gmail.com

\section{- Taran Nina}

$\mathrm{PhD}$, Associate Professor of Hygiene and Ecology №2 National Medical University named after 0 . Bogomolets Address: 01601, ave. Peremohy, 34, Kyiv, Ukraine

Tel.: 0444544930

E-mail: kgpnmu@ukr.net 